\title{
Francis Gingras, La polygraphie à l'œuvre. Du recueil médiéval au roman recyclé
}

\section{Maria Colombo Timelli}

\section{(2) OpenEdition}

\section{Journals}

Édition électronique

URL : http://journals.openedition.org/studifrancesi/5230

DOI : 10.4000/studifrancesi.5230

ISSN : 2427-5856

Éditeur

Rosenberg \& Sellier

\section{Édition imprimée}

Date de publication : 1 décembre 2016

Pagination : 500

ISSN : 0039-2944

\section{Référence électronique}

Maria Colombo Timelli, « Francis Gingras, La polygraphie à l'œuvre. Du recueil médiéval au roman recyclé », Studi Francesi [En ligne], 180 (LX | III) | 2016, mis en ligne le 01 janvier 2017, consulté le 18 septembre 2020. URL : http://journals.openedition.org/studifrancesi/5230 ; DOI : https://doi.org/ 10.4000/studifrancesi.5230

Ce document a été généré automatiquement le 18 septembre 2020.

\section{(c) $(1)$}

Studi Francesi è distribuita con Licenza Creative Commons Attribuzione - Non commerciale - Non opere derivate 4.0 Internazionale. 


\title{
Francis Gingras, La polygraphie à l'œuvre. Du recueil médiéval au roman recyclé
}

\author{
Maria Colombo Timelli
}

\section{RÉFÉRENCE}

FRANCIS GINGRAS, La polygraphie à l'œuvre. Du recueil médiéval au roman recyclé, in Polygraphies. Les frontières du littéraire, sous la direction de Jean-Paul Dufiet et Élisabeth Nardout-Lafarge, Paris, Classiques Garnier, 2015, pp. 29-40.

1 S'interrogeant d'abord sur la pertinence même de la notion de 'polygraphie' dans le contexte historique du Moyen Âge français, F.G. en trouve des exemples éclairants à tous les niveaux de la production littéraire. Premièrement, les auteurs sont souvent des polygraphes par définition, dans la mesure où leur œuvre est diversifiée: que l'on pense à Jean Bodel, auteur de la Chanson des Saisnes, mais aussi de fabliaux et des Congés, ou encore à Adam de la Halle et à Rutebeuf (p.31). Sur un autre plan, deux 'romans' comme Cristal et Clarie et Beaudous de Robert de Blois se construisent, bien que par des modalités d'écriture différentes, par des apports très divers et donnent lieu à une écriture polygraphique cumulative. Enfin, cette figure centrale de la transmission des textes dans le monde médiéval qu'est le copiste s'avère nécessairement un polygraphe, auquel il est fréquemment demandé de produire des manuscrits recueils, au contenu parfois disparate, qui ne cessent de nous surprendre. Loin d'en être étrangère, la «logique polygraphique» (p.38) se situe par conséquent au cœur même de la production littéraire médiévale. 